be enlarged to cover all the territories surrounding the Persian Gulf and that the title of the Branch should be changed to "Middle East Branch."

Rules were adopted, and the meeting then proceeded to elect the following officers and Branch Council:

President: Lieutenant-Colonel C. J. A. O'Kelly (Basra).

Honorary Secretary and Treasurer: Dr. J. J. Todd Morrison (Basra).

Members of Council: Dr. P. C. C. Garnham (London), ex officio (representative of the Branch on the Council of the Association), Dr. A. Anderson (Abadan), Dr. J. Brebner (Abadan), Colonel W. J. Moody (Bahrein), Dr. S. T. Nakib (Basra). One vacancy. It was resolved to ask the Kuwait Medical Society to fill this seat.

On the evening following the meeting a most successful dinner was held at the Port Club, Basra. The guests included Dr. Mohammed Ali Fatta, Director of Medical Services of Iraqi Ports and Navigation, and Mr. and Mrs. R. Keight (British Council).

\section{GENERAL MEDICAL . COUNCIL}

\section{ELECTION OF DIRECT REPRESENTATIVES}

Practitioners in England and Wales will receive within the next few days voting papers for the purpose of electing seven Direct Representatives of the profession to the General Medical Council. The practitioners chosen as the Association's candidates have issued an election address which is set out below. All members of the Association are asked to cast their votes for the signatories to this address.

\section{Election Address}

Dear Sir or Madam,

We, the undersigned medical practitioners, are offering ourselves for election as Direct Representatives of the profession on the General Medical Council.

We believe that the best qualifications for a candidate for the office of Direct Representative are a long and wide experience in the practice of medicine and a sound knowledge of the many difficult and varied problems which confront the profession. We are of the opinion that the nature of these problems makes it important to you personally, and to the profession as a whole, that the Direct Representatives should be in a position to express, with the fullest possible authority and knowledge, the views of the general body of practitioners.

The Medical Act, 1950, has introduced changes in the constitution, functions, and procedure of the General Medical Council, and we submit that our experience will enable us, if elected, to make a useful contribution, within the body of the Council itself, to the discussions on the operation of the new Act.

We are all keenly interested in matters affecting medical education and registration, and the five who are at present serving as Direct Representatives on the General Medical Council already have a thorough knowledge of the discussions which took place before the new Medical Act was presented in Parliament. Our experience should be of special value in connexion with the regulations to be prescribed by the Council regarding the provisional registration of those who have passed a qualifying examination.

If elected, we shall use our influence in maintaining the best traditions and methods of general and consulting practice. Our experience and qualifications are summarized below, and we hope you will feel that, through us, the views of practising doctors will be adequately and forcefully expressed in the General Medical Council.

Reginald Hugh Balfour Barrow, M.D., 37, St. Cross Road, Winchester. Secretary of the Southern Branch of the British Medical Association for the past six years. Chairman of the Hampshire Ophthalmic Services Committee for the past three years. Formerly President of the Southern Branch and Secretary and Chairman of the Winchester Division of the British Medical Association. Member of the Council and of the Central Ethical Committee of the British Medical Association for six years.

James Alexander Brown, M.D., 1,437, Pershore Road, Stirchley, Birmingham. Direct Representative on the General Medical Council since 1947. Chairman of the Representative Body of the British Medical Association, 1949-50. Member of Council of the British Medical Association.

Octavius Cyril Carter, M.B., B.S., M.R.C.S., L.R.C.P., Hursley, Poole Road, Bournemouth. Direct Representative on the General Medical Council since 1949. Member of Council of the British Medical Association. Secretary, Bournemouth Division of the British Medical Association, 1922-45.

HarRY GuY DaIN, M.D., F.R.C.S., Bournbrook House, Selly Oak, Birmingham 29. Direct Representative on the General Medical Council since 1934. Chairman of the Representative Body of the British Medical Association, 1937-42. Chairman of Council of the British Medical Association, 1943-9.

Edward ANDREW GregG, M.D., L.R.C.P.\&S.(I), 14, Oakley Square, London, N.W.1. Direct Representative on the General Medical Council since 1942. Chairman of the Representative Body of the British Medical Association, 1948. Chairman of Council of British Medical Association since 1949. Chairman of the Insurance Acts Committee, 1937-48.

John Thornton Ingram, M:D., F.R.C.P., 27, Park Square, Leeds. Chairman of the Leeds Division of the British Medical Association, 1941-4. Chairman of the Leeds Joint Council of Industrial Medicine, 1942-7. Clinical Sub-dean, Leeds Medical School, since 1945.

Noel Everard Waterfield, O.B.E., M.B., B.S., F.R.C.S., Birchwood, Guildford Road, Little Bookham, Surrey. Direct Representative on the General Medical Council since 1945 Chairman of the Central Ethical Committee of the British. Medical Association, 1935-47; and of the Surrey Local Medical Committee since 1946. Member of Council of Medical Defence Union.

Our candidature has been endorsed by the appropriate Divisions of the British Medical Association.

We give you an assurance that if we are elected we shall devote to your service whatever time and energy may be necessary to the proper fulfilment of our duties as Direct Representatives.

We ask you to accord us your vote, and we shall be grateful for your active assistance in securing the votes of your colleagues.
R. H. BALFOUR BARROW.
J. A. BROWN.
O. C. CARTER.
E. A. Gregg.
J. T. INGRAM.
N. E. WATERFIELD.

H. GuY Dain.

We mistakenly reported in the Supplement of March 31 (p. 136) that the report on the association of the general practitioner with hospital work was approved by the Council at its meeting on March 14. In fact, the report was withdrawn so that it could be considered by the Central Consultants and Specialists Committee and the G.M.S. Committee. 